\title{
Response of Fruit Crops to Climate Aberration, Its Possible Affect in North East India and Mitigation Strategies - A Review
}

\author{
Utpal Barua*, R. P. Das and Bornali Gogoi \\ Department of Horticulture, Assam Agricultural University, Jorhat, Assam, India \\ *Corresponding author
}

Keywords

Climate change, Fruit, Production, Temperature, Yield

Article Info

Accepted:

10 January 2021

Available Online:

10 February 2021

\section{A B S T R A C T}

Climate change is a major threat to biodiversity, ecosystem services, and human wellbeing and will have impact on horticultural crops, due to erratic temperature regime, rainfall, more demand for water and enhanced biotic and abiotic stresses. Global warming has the potential to reduce available winter chill and thus greatly impact yield of temperate fruits and nuts. On the other hand, subtropical and tropical fruit tree species might have the opportunity to spread beyond their current latitudinal belts and to much higher elevations, while others will decline in increasingly adverse locations. Changes in plant phenology are one of the earliest responses to rapid global climate change and could potentially have serious consequences for fruit crops that depend on temperature and rainfall. However, the changes will not be only harmful, as $\mathrm{CO}_{2}$ concentration may enhance faster photosynthesis and increased temperature may hasten the process of maturity. Temperature increase affects photosynthesis directly, causing alterations in sugars, organic acids, and flavonoids contents, firmness and antioxidant activity. Hence there is a need to protect these valuable crops for sustainability against the climate change scenario.

\section{Introduction}

Climate on Earth has changed many times since the existence of our planet, ranging from the ice ages to periods of warmth. Due to its significance on human life, agriculture was one of the first sectors to be studied in terms of potential impacts of climate change (Adams et al., 1990). Many models and modules have been developed, predictions have been made. According to studies carried out by the Intergovernmental Panel on Climate Change (IPCC), average air temperatures will increase between $1.4{ }^{\circ} \mathrm{C}$ and $6.4^{\circ} \mathrm{C}$ by the end of this century. Assad et al., (2004) predicted that in near future rising air temperature could induce more frequent occurrence of extreme drought, flooding or heat waves than in the past. Impacts of climate change on agricultural sector into three broad categories of direct effect, indirect effect and socio economic effect (Kim, 2009). The authors represented the effects of global warming on horticultural crops in ten different categories (fig. 1 and fig. 2).

The North Eastern Region (NER) of India comprising eight states, shares $8 \%$ area of the 
country, has about $72 \%$ area under hilly ecosystems which is characterized by rough fragile marginal terrain and mild to excessive sloping land, rich biodiversity, unique ethnicity and socio-ecological set up. The region receives significantly high rainfall, its varied physiological features and altitudinal differences gives rise to diverse types of climate ranging from near tropical to temperate and alpine. The region has been identified as one of the biodiversity hotspots of India. The annual rainfall in the region is received mainly from south-west monsoon and starts from middle of May and continues till October. On an average, the NE region receives about $2450 \mathrm{~mm}$ of rainfall. The Cherrapunji-Mawsynram range receives rainfall as high as $11,500 \mathrm{~mm}$, annually. The temperature varies from $15^{\circ} \mathrm{C}$ to $32^{\circ} \mathrm{C}$ in summer and 0 to $26^{\circ} \mathrm{C}$ in winter. The region has also suffered from climate change. The rich biodiversity of the region is a good indicator climate change effects over a period of time. The 'South Assam Meteorological Subdivision', covering mainly the hill states of Nagaland, Manipur, Mizoram and Tripura and parts of the Barail Hills in southern Assam, reported a significant change in seasonal rainfall. The summer monsoon rainfall is found to be decreasing over this region significantly during the last century at an approximate rate of $11 \mathrm{~mm}$ per decade (Das, 2004; Mirza et al., 1998). Analysis of long-term temperature data for the region points to a distinctly rising trend in surface air temperatures. The annual mean maximum temperatures in the region are rising at the rate of $+0.11^{\circ} \mathrm{C}$ per decade. The annual mean minimum temperatures are also increasing at a rate of $0.04^{\circ} \mathrm{C}$ per decade in the region (Das, 2004).

For any successful fruit crop cultivation climate plays an important role. Fruit crops respond to climatic changes by altering phenological, physiological processes. There is loss of vigour, fruit bearing ability, reduction in size of fruits, less juice content, low colour, reduced shelf life and increasing attack of pests resulting low production and quality of many fruits. Abnormal high temperature during winter cause poor flowering, irregularity in flowering duration, pattern of flowering and poor yield in pear due to non-availability of sufficient chilling hours during winter months (Hazarika, 2013). The impacts of climate change in north eastern region are less studied and less known, making the future scenarios more uncertain for vulnerability assessment and risk management.

\section{Resource availability}

The characteristic features of NE fruit crop production system is rainfed, use of local varieties, limited use of agro-chemicals, low moisture retention capacity of upland soil and traditional management practices. Problems of high rainfall $(12.10 \%$ of the country's total precipitation), soil acidity, aluminum toxicity in upland and iron toxicity are abundant. The steep hilly slopes are vulnerable to sheets and gullies erosions, resulting in barren rocky slopes. The major fruit crops are pineapple (Ananas comosus), banana (Musa spp.), passion fruit (Passiflora edulis), khasi mandarin (Citrus reticulate) and kachai lemon (Citrus jambhiri). Recently temperate fruit crops like kiwifruit (Actinidia deliciosa) and plum (Prunus domestica) have gained popularity. Northeast India is the citrus depository, where many citrus species are originated. Khasi mandarin (Citrus reticulata) is widely cultivated and Sweet orange (Citrus sinensis) is also commercially grown in some of the places. Maximum genetic variability of Musa acuminate and M. balbisiana occurs in NE India. M. flaviflora is localized to Manipur and Meghalaya. Rich diversity occurs in Pyrus, Rubus, Ribes and Prunus. The Shillong plateau of Khasi hills in 
Meghalaya have many Prunus species such as $P$. nepalensis, $P$. undulate and $P$. cerasoides. Pyrus pyrifolia var. cubha makai ( $P$. serotina Red) and some of them are grown semi commercially in Meghalaya. A large number of other tropical and subtropical fruits belonging to the genera Garcinia, Artocarpus, Phyllanthus, Annona, Averrhoa, Persia, Aegle, Passiflora and Tamarindus etc., are found growing wild in the region. Jackfruit is indigenous to the region and grows abundantly in Tripura, Assam, Nagaland and Meghalaya with a large number of cultivars and land races.

\section{Vulnerability due to vagaries of temperature and water availability}

High temperatures can increase the capacity of air to absorb water vapor and consequently generate a higher demand for water. Higher evapotranspiration indices could lower or deplete the water reservoir in soils, creating water stress in plants during dry seasons. Water stress is of great concern in fruit production, because fruit trees are not irrigated in many production areas of $\mathrm{NE}$ region. It is well documented that water stress not only reduces crop productivity but also tends to accelerate fruit ripening (Henson, 2008). During their development, high temperatures can affect photosynthesis, respiration, aqueous relations and membrane stability as well as levels of plant hormones, primary and secondary metabolites. Ultimately it causes morphological, anatomical, physiological, biochemical changes in plant tissues and as a consequence can affect growth and development of different plant organs. These events can cause drastic reductions in commercial yield. Seed germination can be reduced or even inhibited by high temperatures, depending on the species and stress level (Bewley, 1997). Ambient temperatures for the development of fruit crops are much narrower and depending on the species and ecological origin, it can be pushed towards $0^{\circ} \mathrm{C}$ for temperate species from cold regions, similarly, they can reach $40^{\circ} \mathrm{C}$ in species from tropical regions. A general temperature effect in plants involves the ratio between photosynthesis and respiration. For a high yield, not only photosynthesis should be high but also the ratio photosynthesis/respiration should be much higher than one. At temperatures around $15^{\circ} \mathrm{C}$, the above mentioned ratio is usually higher than ten, explaining why many plants tend to grow better in temperate regions than in tropical ones (Went, 1953). Higher than normal temperatures affect the photosynthetic process through the modulation of enzyme activity as well as the electron transport chain (Sage and Kubien, 2007). Additionally, in an indirect manner, higher temperatures can affect the photosynthetic process increasing leaf temperatures and, thus, defining the magnitude of the leaf-to-air vapor pressure difference, a key factor influencing stomatal conductance (Lloyd and Farquhar, 2008). Temperature is of paramount importance in the establishment of a harvest index. The higher the temperature during the growing season, the sooner the crop will mature. Kiwi grown under higher temperatures matured earlier that the same crops grown under lower temperatures. Due to rise in temperature, crops will develop more rapidly and mature earlier (Hall et al., 1996; Wurr et al,. 1996). For example, citrus, grapes, melons etc. will mature earlier by about 15 days. Strawberries will produce more runners at the expense of fruits. Specific chilling requirements of pome and stone fruits will be affected hence dormancy breaking will be earlier. High temperature and moisture stress also increase sunburn and cracking in apples and increase in temperature at maturity will lead to fruit cracking and burning in litchi (Kumar and Kumar, 2007). Banana cultivation may suffer from high temperature, soil moisture stress or 
flooding/water logging. In Banana, leaf production increases by one leaf per month for every 3.3 to $3.7^{\circ} \mathrm{C}$ rise in minimum or mean temperature from $10-20^{\circ} \mathrm{C}$ or 13.5 to $25^{\circ} \mathrm{C}$ respectively. Higher temperature (31$32^{\circ} \mathrm{C}$ ), in general, increases the rate of plant maturity in annual species, thus shortening the growth stages, during which developing fruits and suckers absorb photosynthetic products. The temperature below $10^{\circ} \mathrm{C}$ leads to impedance of inflorescence and malformations of bunches. Chilling symptoms on leaves are not seen immediately but it may take 2 to 4 days to appear (Datta, 2013). In banana, Flooding for more than $48 \mathrm{hrs}$ severely reduces growth and after 72-96 hrs, no recovery of mature shoots. Water logging in robusta plant reduces the bunch weight. Higher temperature $31-32^{\circ} \mathrm{C}$, increases the rate of plant maturity \& shorten the growth stages. High air temperatures $38^{\circ} \mathrm{C}$ and bright sunshine causes choked plant, sunburn damage to fruit. Dwarf Cavendish, temperature below $10^{\circ} \mathrm{C}$ leads to impedance of inflorescence and malformations of bunches. Choked bunches are prone to sunburn (Singh, 2012). Wild species of banana namely Ensete glaucum, Musa cheesmanii, M. magnesium, M. balbisiana, etc. are abundantly found in Manipur. The impact of climate change on these crops is of high relevance. Shortening the growing period, decrease in water availability and poor vernalization are expected to decrease potential yields. Plants requiring high humidity and water may face challenges for survival. Due to changing climate, high temperature conditions are expected to be prevalent throughout the growing period which will increase temperature stress on the crops. This can disturb the biochemical reactions in plants essential for normal cell function. The photosynthetic functions of higher plants will be affected adversely. Delay in monsoon, dry spells of rains and untimely rains during water stress period, supra-optimal temperatures during flowering and fruit growth, hailstorms are some of the most commonly encountered climatic conditions experienced by the citrus growers over the past decade or so. In citrus severe water stress causes reduction in leaf initiation, leaf size gets reduced and leaves become leathery and thick. Root growth is adversely affected by water stress. It may lead to increased rooting depth and higher proportion of feeder roots. Rainfed cashew crop is highly sensitive to changes in climate and weather vagaries, particularly during reproductive phase. Cashew requires relatively dry atmosphere and mild winter $\left(15-20^{\circ} \mathrm{C}\right)$ coupled with moderate dew during night for profuse flowering. High temperature $\left(>34.4^{0} \mathrm{C}\right)$ and low relative humidity $(<20 \%)$ during afternoon causes drying of flowers, resulting in yield reduction. Unseasonal rains and heavy dew during flowering and fruiting period aggravated the incidence of pests and diseases. All these situations resulted in reduction yield upto 50 to $65 \%$. Monoembryonic mango cultivars tend to be more cold tolerant than polyembryonic cultivars, probably due to their origin of evolution. However, mango trees can tolerate temperatures up to $48^{\circ} \mathrm{C}$ for short periods and have limited tolerance to cold. Early flowering in the sub-tropics may result in a low fruit set because of several abnormalities caused due to low night temperatures coupled with unseasonal rains. Late flowering also reduces the fruit set because of pseudo-fruit setting leading to clustering disorder. High temperatures during panicle development in mango speed up growth and reduce the number of days for effective pollination when hermaphrodite flowers are available, which may lead to unsatisfactory production. Unseasonal rains coupled with variation in temperature and humidity can make mango trees flower during off season, but fruit set will be poor because of the showers. Rising temperatures cause desiccation of pollen and 
poor pollinator activity resulting in low fruit set and, ultimately, a poor crop. Flower buds exposed to cold temperature during night may change into vegetative ones under the warm night conditions. In the tropics, cool winters followed by a rise in day temperatures as summer approaches may result in poor flowering. Cool temperatures during inflorescence development reduce the number of perfect flowers (Bhruguvanshi, 2009). In papaya, higher temperatures have resulted flower drops in female and hermaphrodite plants as well sex changes in hermaphrodite and male plants. The promotion of stigma and stamen sterility in papaya is mainly because of higher temperatures. In grapes, degree-days are important in determining the timing of various phenological events where, a temperature regime of $10^{\circ} \mathrm{C}$ and temperatures between $28-32^{\circ} \mathrm{C}$ are most congenial. Variations in temperature cause alterations in the developmental stages and ultimately the ripening time. Under a higher temperature regime, the number of clusters per shoot was greater and the number of flowers per cluster was reduced (Pouget, 1981). Kliewer (1977) demonstrated the loss of ovule viability in the varieties Pinot Noir and Carignane at $35^{\circ} \mathrm{C}$ and $40^{\circ} \mathrm{C}$ as compared to $25^{\circ} \mathrm{C}$. High temperatures also reduce colour development. In the case of guava, it has been observed that red colour development on the peel of guava requires cool nights during fruit maturation. Varieties like Apple Colour, which have attractive apple skin colour under sub-tropical conditions, have red spots on the skin under tropical South Indian conditions (Rajan, 2008). In pineapple, the impact of temperature variations can be seen from studies where induction of flowering takes place because of reduction in temperature, short day lengths or both (Friend, 1981). The coincidence of long days with high temperatures results in irregular flowering. Cultivation of temperate fruits like apples moving to further higher elevations. Taking the example of Himachal Pradesh where apple productivity in Bajaura valley decreased by $2-3 \%$ due to climate change. Apple has been replaced by off-season vegetables. In more recent years, apple in Kullu valley has been replaced by pomegranate and kiwi fruit. In over a decade, cooler Lahoul valley has recorded a remarkable increase of more than $122 \%$ in area under apple, while productivity of ruling seasonal crops like potato and pea has declined by 11-15\% (Ghosh, 2012). Similar trends have been reported from Arunachal Pradesh. Bharali and Khan (2011) in a study from Mechuka of Arunachal Pradesh found that, 15-20 years ago the apples in Mechuka were sweet, but now the fruits taste sour. Earlier apples used to flower only once in a year during February. Now they flower twice a year, in late March and September. The flowers that bloom in March produce fruits, while those that bloom in September do not produce any fruits.

Extreme precipitation will cause crop yield variation. Increase in pest and disease incidence as well as increase in evaporation and runoff will decrease the soil moisture recharge. Pollination is crucial for reproduction of most flowering plants. Climate change may reduce the activity of pollinating agents and pose a serious threat to pollination services, which may lead to floral abortion. Climate change and $\mathrm{CO}_{2}$ concentration is likely to alter key interactions between horticultural plants and pollinators, insect pests, diseases and weeds. Melting of ice cap in the Himalayan regions is likely to reduce the chilling availability for flowering plants. This may result in less abundant flowering or no bloom, while some other plants will be threatened. Evidences show that many plant species shift their geographical habitats to combat regional climatic variation. Many species are unable to acclimatize to the pace of climatic variations. Stability in environmental conditions is essential for 
alpine regions, where many species may disappear altogether. So, these changes may increase the extinction risk.

\section{Vulnerability due to exposure of carbon dioxide and ozone}

The greenhouse effect is primarily a combination of the effects of water vapor, $\mathrm{CO}_{2}$ and minute amounts of other gases (methane, nitrous oxide, and ozone) that absorb the radiation leaving the Earth's surface. Since a significant part of all the energy emanated from Earth occurs in the form of infrared radiation, increased $\mathrm{CO}_{2}$ concentrations mean that more energy will be retained in the atmosphere, contributing to global warming. $\mathrm{CO}_{2}$ concentrations in the atmosphere have increased approximately $35 \%$ from pre-industrial times to 2005 (IPCC, 2007). Besides industrial activities, agriculture also contributes to the emission of greenhouse gases. $\mathrm{CO}_{2}$ and $\mathrm{O}_{3}$ concentrations in the atmosphere are changing during the last decade and are affecting many aspects of fruit crops production around the globe (Felzer et al., 2007; Lloyd and Farquhar, 2008). If atmospheric $\mathrm{CO}_{2}$ concentration is doubled, the overall growth of $\mathrm{C}_{3}$ plant will increase, thus, resulting in increased marketable yield (30-40\%). But the positive impacts of increased $\mathrm{CO}_{2}$ concentration will be nullified by increased temperature and scarcity of water resulting in decreased production. Han et al., (2012) showed the effects of $\mathrm{CO}_{2}$ level on tree growth and fruit characteristics of 'Niitaka' pear. Fruit weight was the highest in elevated $\mathrm{CO}_{2}$ group, but lowest in elevated temperature group. Flesh firmness at harvest was the highest in elevated temperature group. Soluble solids content increased at harvest time in groups with elevated $\mathrm{CO}_{2}$. Rising $\mathrm{CO}_{2}$ concentration alone may increase mango production and water use efficiency, but comprehensive studies predict decreases in yield of mango when increasing temperature and changes in solar radiation are considered simultaneously. In grape elevated atmospheric $\mathrm{CO}_{2}$ levels significantly effects fruit dry weight, with increase in tartaric acid and total sugars contents.

$\mathrm{O}_{3}$ concentration in the atmosphere is also increasing. Even low levels of $\mathrm{O}_{3}$ in the vicinities of big cities can cause visible injuries to plant tissues as well as physiological alterations (Felzer et al., 2007). The effects of $\mathrm{O}_{3}$ on vegetation have been studied both under laboratory and field experiments. Stomatal conductance and ambient concentrations are the most important factors associated with $\mathrm{O}_{3}$ uptake by plants. $\mathrm{O}_{3}$ enters plant tissues through the stomatas, causing direct cellular damage, especially in the palisade cells (Mauzerall and Wang, 2001). The damage is probably due to changes in membrane permeability and may or may not result in visible injury, reduced growth and, ultimately, reduced yield (Krupa and Manning, 1988). Visible injury symptoms of exposure to low ozone concentrations include changes in pigmentation, also known as bronzing, leaf chlorosis, and premature senescence (Felzer et al., 2007). Additionally, Percy et al., (2003) observed that $\mathrm{O}_{3}$ exposure causes reduction in photosynthesis and increased turnover of antioxidant systems.

\section{Abnormality in quality parameters and ripening}

Extensive work has been carried out for more than three decades focusing quality properties of fruit crops exposed to high temperatures during growth and development. Flavor is affected by high temperatures. Apple fruits exposed to direct sunlight had a higher sugar content compared to those fruits grown on shaded sides (Brooks and Fisher, 1926). Grapes also had higher sugar content and lower levels of tartaric acid when grown under high temperatures (Kliewer and Lider 
1968, Kliewer and Lider 1970). Coombe (1987) observed that a $10^{\circ} \mathrm{C}$ increase in growth temperature caused a $50 \%$ reduction in tartaric acid content. Kliewer and Lider (1970) and Lakso and Kliewer (1975) verified that malic acid synthesis was more sensitive to high temperature exposure during growth than was the synthesis of tartaric acid. Fruit firmness is also affected by high temperature conditions during growth. 'Fuerte' avocados exposed to direct sunlight $\left(35^{\circ} \mathrm{C}\right)$ were 2.5 times firmer than those positioned on the shaded side $\left(20^{\circ} \mathrm{C}\right)$ of the tree (Woolf et al., 2000).'Hass' avocados grown under high ambient temperatures $\left(45 \pm 2^{\circ} \mathrm{C}\right)$ had higher moisture content at harvest than fruit grown under lower temperatures $\left(30 \pm 2^{\circ} \mathrm{C}\right)$. They also noted that higher temperature influenced oil composition, where the concentration of certain specific fatty acids increased. Avocados with higher dry matter content take longer to ripen which could pose a serious problem for growers planning to market their fruits immediately after harvest (Woolf et al., 1999).

Thus, fruit growers, packers and shippers must pay close attention to ambient temperatures during growth and development as well as maturity indices to assure harvest at the appropriate time. Mineral accumulation was also reported to be affected by high temperatures and/or direct sunlight. 'Hass' avocado fruits exposed to direct sunlight showed higher calcium (100\%), magnesium (51\%)and potassium (60\%) contents when compared to fruits grown under shaded conditions (Woolf et al., 1999). High temperatures also appeared to reduce monoterpenes (Muscat flavor) in grapes. Linalool, an important monoterpene was also higher at low temperature (Zemni et al., 2005). Antioxidants in fruit crops can also be altered by exposure to high temperatures during the growing season. Wang and Zheng (2001) observed that 'Kent' strawberries grown in warmer nights $\left(18-22^{\circ} \mathrm{C}\right)$ and warmer days $\left(25^{\circ} \mathrm{C}\right)$ had a higher antioxidant activity than berries grown under cooler $\left(12^{\circ} \mathrm{C}\right)$ days. The investigators also observed that high temperature conditions significantly increased the levels of flavonoids and, consequently, antioxidant capacity. Galletta and Bringhurst (1990) verified that higher day and night temperatures had a direct influence in strawberry fruit color. Berries grown under those conditions were redder and darker. McKeon et al., (2006) also reported higher temperatures tends to reduce vitamin content in fruit crops.

Grape berries exposed to direct sunlight ripened faster than those ripened in shaded areas within the canopy (Kliewer and Lider, 1968). Ripening of 'Hass' avocados was also affected by exposure to high temperatures during growth and development. For fruits exposed to direct sunlight, pulp temperatures reached $35^{\circ} \mathrm{C}$ and required 1.5 days longer to ripen than those than grew in the shade (Woolf et al., 1999). 'Fuerte' and 'Hass' fruits exposed to direct sunlight were firmer than fruits of the shaded areas. Cell wall enzyme activity (cellulose and polygalacturonase) was negatively correlated with fruit firmness, indicating that sun exposure, i.e., higher temperatures during growth and development, can delay ripening. However, in apples, treatments of 38 and $40^{\circ} \mathrm{C}$ for 2-6 days did not have marked effects on respiration, although ethylene production was reduced (Liu, 1978, Porritt and Lidster, 1978). The above studies suggest that changes in ripening behavior are likely to occur when fruit crops are exposed to higher temperatures prior to harvest.

\section{Climate change effect on physiological disorders, harvest and postharvest}

Air pollution also significantly reduced the yield of several horticultural crops and 
increases the intensity of certain physiological disorders like black tip of mango which is induced by coal fume gases, sulphur dioxide, ethylene, carbon monooxide and fluoride. Exposure of fruit crops to high temperatures can result in physiological disorders and other associated internal and external symptoms. It is also well known that exposure of fruit to temperature extremes approaching $40^{\circ} \mathrm{C}$ can induce metabolic disorders and facilitate fungal and bacterial invasion. Frequent exposure of apple fruit to high temperatures, such as $40^{\circ} \mathrm{C}$, can result in sunburn, development of water core and loss of texture (Ferguson et al., 1999). Moretti et al., (2010) enumerated the adverse effect to heat and $\mathrm{CO}_{2}$ on fruit crops (Table 1 and Table 2).

Table.1 Symptoms of heat and solar injury of fruit crops

\begin{tabular}{|l|l|}
\hline Crop & Symptom \\
\hline Apple & Skin discoloration, pigment breakdown and water soaked areas \\
\hline Avocado & $\begin{array}{l}\text { Skin and flesh browning, increased decay susceptibility, affect fruit size \& } \\
\text { capacity to 'store' mature crop on the avocados tree }\end{array}$ \\
\hline Lime & Juice vesicle rupture, formation of brown spot on the fruit surface \\
\hline Pineapple & $\begin{array}{l}\text { Flesh with scattered water soaked areas, translucent fruit flesh, irregular } \\
\text { flowering. }\end{array}$ \\
\hline Strawberry & $28-30^{\circ} \mathrm{C}$ runner production commences and flower production decreases \\
\hline
\end{tabular}

Source: Moretti et al., (2010)

Table.2 Physiological and quality parameters of fruit crops affected by exposure to increased $\mathrm{CO}_{2}$ levels

\begin{tabular}{|c|c|c|}
\hline Physiological and quality parameter & Effect of high $\mathrm{CO}_{2}$ & Crop \\
\hline \multirow[t]{3}{*}{ Respiration } & $\downarrow$ & Blueberries \\
\hline & 4 & Lemon, mango \\
\hline & $=$ & Apples \\
\hline Firmness & 4 & Strawberry, raspberry \\
\hline Colour intensity & 4 & Grape \\
\hline Alcohol & $\uparrow$ & Grape, mango, pear \\
\hline Titratable acidity & $=$ & Grape \\
\hline Ascorbic acid & $\uparrow$ & Strawberry, orange \\
\hline Total phenol, Anthocyanin & 4 & Grape, strawberry \\
\hline Flavanoid, pH & $\uparrow$ & Grape \\
\hline Volatile compound & $\downarrow$ & Mango \\
\hline Antioxidant capacity & $\downarrow$ & Strawberry \\
\hline
\end{tabular}

Source: Moretti et al., (2010) 
Fig.1 Potential impacts of climate change on the agricultural sector (source: Kim, 2009)

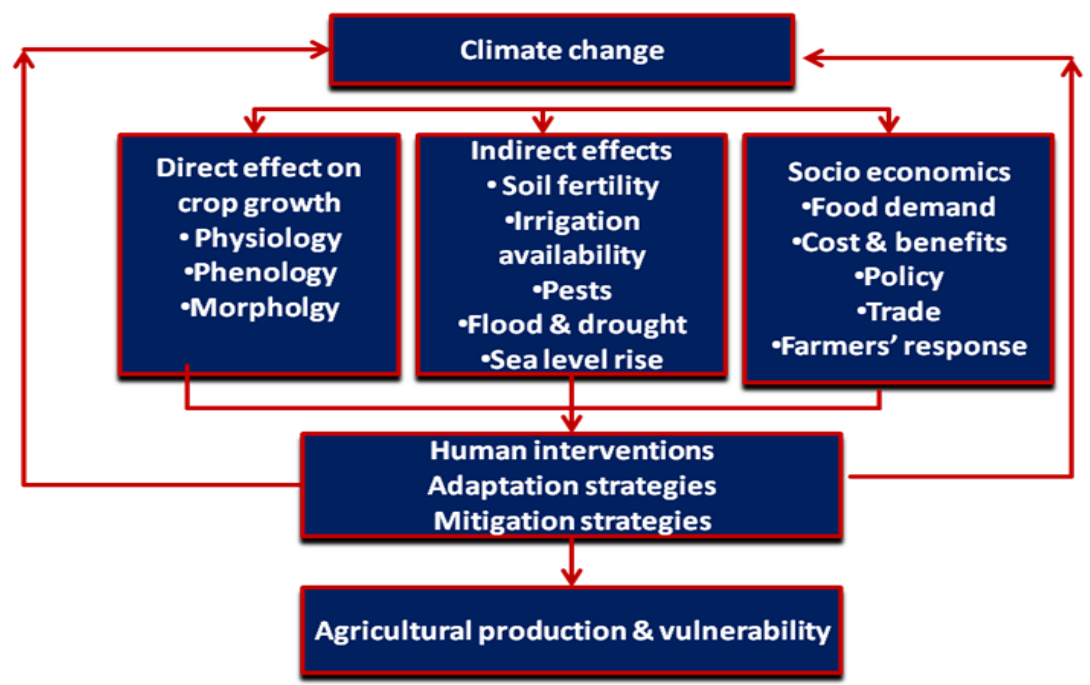

Fig.2 Potential impacts of global warming on the Horticulture sector (source: Kim, 2009)

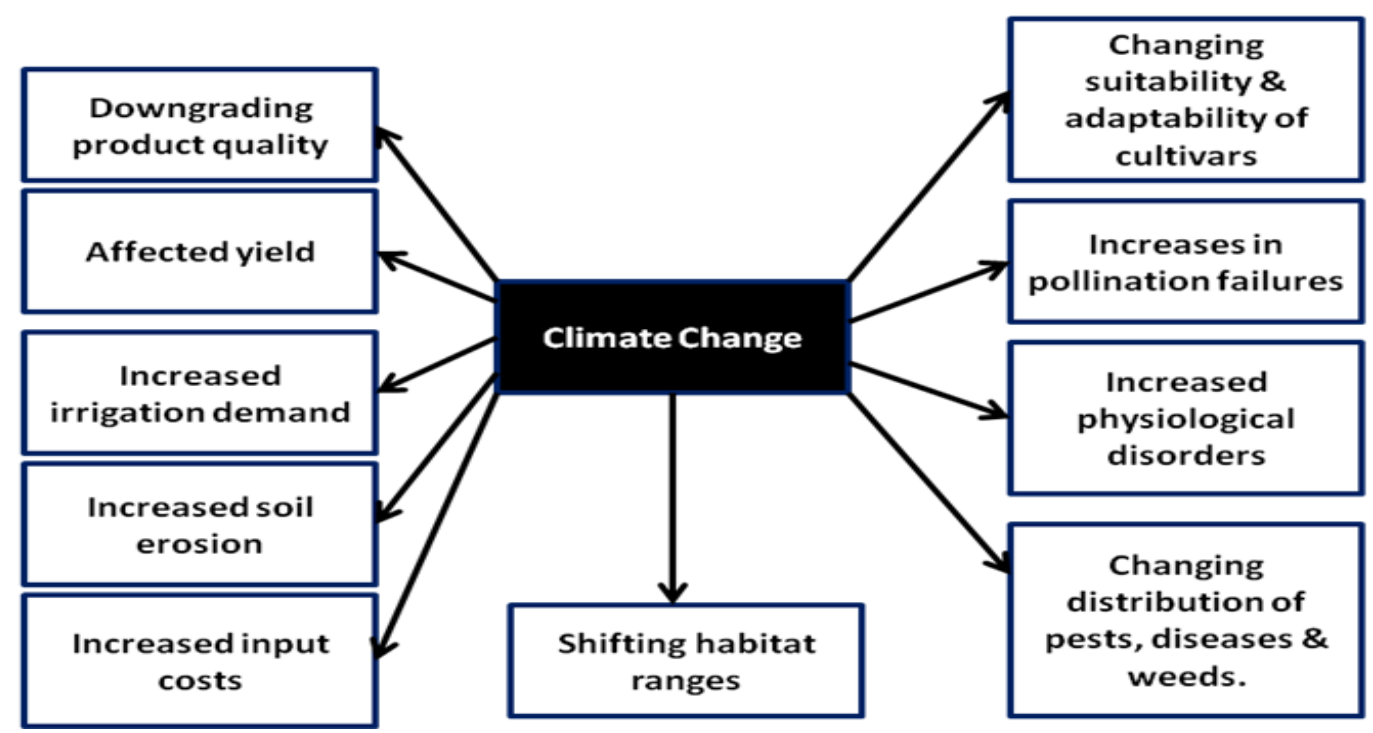

Climatic fluctuations are also known to affect post-harvest quality of fruits and affect food safety during storage. Fruit are generally cooled after harvest and before packing operations. It removes field heat from fresh produce, based on the principle that shelf-life is extended 2 to 3 fold for each $10^{\circ} \mathrm{C}$ decrease in pulp temperature. By reducing the respiration rate and enzyme activity, produce quality is extended as evidenced by slower ripening/senescence, maintenance of firmness, inhibition of pathogenic microbial growth and minimal water loss (Talbot and Chau, 2002). It is anticipated that under warmer climatic conditions, fruit crops will be harvested with higher pulp temperatures, which will demand more energy for proper cooling and raise product prices.

Ozone also showed the capability of removing ethylene from the environment, inside cold rooms. Strawberries cv. Camarosa 
stored for three days under refrigerated storage $\left(2^{\circ} \mathrm{C}\right)$ in $\mathrm{O}_{3}$ enriched atmosphere $(0.35$ $\mu 1 ~^{-1}$ ) showed a threefold increase in vitamin $\mathrm{C}$ content when compared to berries stored at the same temperature under normal atmosphere (Perez et al., 1999).

\section{Changes in pest and diseases incidence}

It is now recognized that climate change will affect plant diseases together with other components of global change. Direct effects on plant health by climate warming, increased pollutants and $\mathrm{CO}_{2}$ concentrations will be accompanied by the easier introduction of exotic invasive species. Introductions of novel plant pathogens have already occurred in many regions, but climate changes are likely to often facilitate their further establishment and spread. High temperatures coupled with high rainfall and humidity help in building up ideal conditions for the growth of a number of disease pathogens. The powdery mildew disease in mango is a sporadic but serious disease of mango inflorescence that can cause up to $80-90 \%$ losses of the crop in extreme cases. Optimal disease development occurs at $10-31^{\circ} \mathrm{C}$ and $60-90 \%$ RH. Chhata et al., (2006) reported that high humidity (85-90\%), moderate temperatures provided favourable condition for the initiation of disease.

Correlations between weather parameters like different maximum temperature regimes and sunshine hours had negative correlations with disease development, while minimum temperature, humidity and wind speed had positive correlations. However, in a study conducted by Kumar (2010) has shown that in mango cv. Chausa the rate of development of fruit fly increased with the increase in temperature from $20-35^{\circ} \mathrm{C}$. The percent larval survival, adult emergence and growth index also increased with an increase in temperature from 20 to $27^{\circ} \mathrm{C}$ and thereafter decreased up to $35^{\circ} \mathrm{C}$. Thus a temperature of $27^{\circ} \mathrm{C}$ was found to be ideal for survival and development of the immature stage and reproduction of Bractocera dorsalis. Downy mildew is found worldwide wherever grapes are grown, occurring primarily where warm, humid conditions exist during the growing season. Unseasonal rains coupled with higher temperatures during vegetative phases in grapes will result in damage due to this disease (Pearson and Goheen, 1988). Dry spell during flower emergence and fruit set affects flower initiation and aggravates incidence of pest (Psylla).

\section{Future Line of Work}

Climate smart horticulture is not a single specific agricultural technology or practice that can be universally applied. It is an approach that requires site specific assessments to identify suitable production technologies and practices to address multiple challenges faced by agriculture and food systems simultaneously and holistically. There is need to analyze and understand about climate change at regional levels in relation to both annual and perennial fruit crops (Malhotra, 2017). Technological intervention for climate smart agriculture is an integral part of the local climate change action. Cover cropping, in-situ residue management and restoration of degraded lands for soil moisture conservation can improve C-sequestration. Integrated farming systems for soil and moisture conservation and nutrient recycling could be answer for better sustainability. Water conservation through In-situ methods like land configuration, mulching and ex-situ methods ponds, micro water harvesting structure (jalkund) can be helpful for orchards to coop up with water stress. Promotion of technologies that enhance biological $\mathrm{N}$ fixation and improve nutrient and water use efficiency to reduce $\mathrm{N}_{2} \mathrm{O}$ emission. Creating of new varieties, rootstocks suited to the changing climate may escape climatic 
vagaries. Crop like grapes, where rootstocks Dogridge have shown remarkable adaptability. Several studies have shown that rootstocks have influenced the scion cultivars. Sharad Seedless recorded maximum water use efficiency (WUE) when budded on Dogridge followed by Flame Seedless on Dogridge rootstock at $50 \%$ moisture stress (Sathisha and Prakash, 2005).

Selection of appropriate rootstocks in various fruit crops like mango and guava to suit the changed climatic conditions could be one of the solutions for combating temperature change. Along with such rootstocks, one can consider the use of certain specific species that are better adapted to changed conditions. For instance, several fruit crops have modified physiological and morphological adaptations and withstood these changes well. Fig has adapted to retain high bound water in the tissue, by having sunken stomata, thick cuticle and waxy coating on the leaves. Underutilized fruits like ber (Ziziphus mauritiana L.), phalsa (Grewia asiatica L.) and tamarind (Tamarindus indica L.) also have sunken stomata, thick cuticle and waxy coating of the leaves. Indian gooseberry or Aonla (Emblica officinalis L.) have adapted by reducing leaf area, thereby reducing the transpirational area. Pomegranate (Puncia granata L.) is fairly winter hardy and also drought tolerant. Aonla, being a hardy and drought tolerant sub-tropical tree, can be grown well under tropical conditions.

Papaya (Carica papaya L.) has adapted well to both tropical and sub-tropical conditions, which is also the case with guava. Through pruning and cultural manipulations, grapes, which are basically a temperate crop, are able to have their vines adapt well to the tropics. Pineapple being a CAM plant, has remarkable adaptability to different climatic regimes and has high water use efficiency. There are some germplasms like drought tolerant varieties of pomegranate hybrid Ruby, annona hybrid Arka Sahan, fig selections like Deanna and Excel; salinity tolerant grape root-stock Dogridge (Vitis champine), mango rootstock Bappakai, guava psidium nidle and psidium catellianum and Rangpur lime and Cleopatra mandarin in citrus. These crops and many other fruit crops viz., custard apple, jamun, wood apple, bael, avocado, passion fruit and karonda could be considered as candidate crops under climate change conditions.

Future work can be carried out on the lines given below -

Evaluation of wild species, landraces should be probed thoroughly, which could be a source of resistant genes for tying over adversaries of the temperature.

There is a need to develop and test the performance of different genotypes across several environments so that their suitability can be judged.

Development or location of rootstocks that can tolerate biotic stresses induced by temperature regimes is needed.

Adoption of improved agro-techniques like mulching and cover crops in orchards will help in bringing down the orchard temperature.

Use of precision farming methods would help in maintaining the ground cover within the orchard thereby reducing the temperature and providing an ideal microclimate.

In conclusion the understanding how climate changes will impact mankind in the decades to come is of paramount importance for our survival. The aberrant climatic parameters directly and indirectly affect the production and quality of fruit around the world. Therefore, in the changing climate scenario we need to have a robust and systematic action plan to counter the ill effects and thereby sustaining our production, productivity and quality of fruit crops. 


\section{References}

Adams, R.M., Rosenzweig, C., Peart, R.M., Ritchie, J.T., McCarl, B.A. and Glyer, J.D., 1990. Global climate change and US agriculture. Nature, 345, 219-224.

Assad, E.D., Pinto, H.S., Zullo, J.Jr. and Avila A.M.H., 2004. Impacto das mudançasclimáticas no zoneamentoagroclimático do café no Brasil. PesquisaAgropecuáriaBrasileira, 39, 1057-1064.

Bewley, J.D., 1997. Seed germination and dormancy. The Plant Cell, 9(7): 10551066.

Bharali, S. and Khan, M.L., 2011. Climate change and its impact on biodiversity; some management options for mitigation in Arunachal Pradesh. Current science. 101(7): 855-860.

Bhruguvanshi, S.R., 2009. Implications of climate change in mango. Impact Assessment of Climate Change for Research Priority Planning in Horticultural Crops. Central Potato Research Institute, Shimla, pp 43-46.

Brooks, C. and Fisher, D.F., 1926. Some high temperature effects in apples: Contrasts in the two sides of an apple. Journal of Agricultural Research, 23, 1-16.

Chhata, L.K., Jat, M.L., Ram, J. and Jain, L.K., 2006. Effect of weather variables on outbreak and spread of leaf spot fruit spot in pomegranate. Current Agriculture, 30(1/2): 39-44.

Coombe, B.G., 1987. Influence of temperature on composition and quality of grapes. Acta Horticulturae. 206, 23-35.

Das, P.J. 2004. Rainfall regime of Northeast India: A hydrometeorological study with special emphasis on the Brahmaputra basin. Ph.D. thesis, Gauhati University, Assam, India.

Datta, S., 2013. Impact of Climate Change In Indian Horticulture- A Review. International Journal of Science, Environment and Technology. 2(4): 661671.
Felzer, B.S., Cronin, T., Reilly, J.M., Melillo, J.M. and Wang, X., 2007. Impacts of ozone on trees and crops. Compters Rendus Geoscience. 339, 784-798.

Ferguson, I., Volz, R. and Woolf, A., 1999. Preharvest factors affecting physiological disorders of fruit. Postharvest Biology and Technology. 15, 255-262.

Friend, D.J.C., 1981. Effect of night temperature on flowering and fruit size in pineapple (Ananas comosus (L) Merrill). Botanical Gazette. 142(2): 188-90.

Galletta, G.J. and Bringhurst, R.S. 1990. Strawberry management. In: Small fruit crop management (Eds.) G. J. Galletta and R. S. Bringhurst. Prentice-Hall: Englewood Cliffs. Pp. 83-156.

Ghosh, S.P., 2012. Carrying capacity of Indian horticulture. Current Science. 102(6): 889-893.

Hall, A.J., McPherson, H.G., Crawford, R.A. and Seager, N.G., 1996. Using earlyseasonmeasurements to estimate fruit volume at harvest in kiwifruit. New Zealand Journal of Crop and Horticultural Science. 24, 379-391.

Han, J.H., Cho, J.G., Son, I.C., Kim, S.H., Lee, I.B., Choi, I.M. and Kim, D., 2012. Effects of Elevated Carbon Dioxide and Temperature on Photosynthesis and Fruit Characteristics of 'Niitaka' Pear (Pyrus pyrifolia Nakai). Horticultural Environment Biotechnology. 53(5): 357361.

Hazarika, T.K., 2013. Climate Change and Indian Horticulture: Opportunities, Challenges and Mitigation Strategies. International Journal of Environmental Engineering and Management. 4(6): 629630.

Henson, R. 2008. The rough guide to climate change (2nd ed.). Penguin Books, London, 384.

IPCC Climate change. 2007. In: The physical science basis contribution of working group into the fourth assessment report of the intergovernmental panel on climate change (Eds.) S. Solomon, D. Qin, M. Manning, Z. Chen, M. Marquis, K. B. 
Averyt, M. Tignor and H. L. Miller. Cambridge, United Kingdom: Cambridge University Press. 996.

Kim, C.G. 2009. Impacts and Countermeasures of Climate Change in Korean Agriculture. Research Report No. 593. Korea Rural Economic Institute (in Korean).

Kliewer, M.W., 1977. Effect of high temperature during the bloom-set period on fruit-set, ovule fertility, and berry growth of several grape cultivars. American Journal of Enology and Viticulture. 28, 215-221.

Kliewer, M.W. and Lider, L.A., 1968. Influence of cluster exposure to the sun on the composition of Thompson seedless fruit. American Journal of Enology and Viticulture. 19, 175-184.

Kliewer, M.W. and Lider, L.A., 1970. Effects of day temperature and light intensity on growth and composition of Vitis vinifera L. fruits. Journal of the American Society for the Horticultural Science. 95, 766769.

Krupa, S.V. and Manning, W.J., 1988. Atmospheric ozone: Formation and effects on vegetation. Environmental Pollution. 50, 101-137.

Kumar, R., 2010. Effect of temperature on growth, development and reproduction of fruit fly Bractocera dorsalis Hendel (Diptera: Tephritidae) in mango. Journal of Eco friendly Agriculture. 5(2): 150-53.

Kumar, R. and Kumar, K.K., 2007. Managing physiological disorders in litchi. Indian Horticulture. 52 (1): 22-24.

Lakso, A.N. and Kliewer, W.M., 1975. The influences of temperature on malic acid metabolism in grape berries I. Enzyme responses. Plant Physiology. 56, 370 372.

Lloyd, J. and Farquhar, G.D., 2008. Effects of rising temperatures and $\left[\mathrm{CO}_{2}\right]$ on the physiology of tropical forest trees. Philosophical Transactions of the Royal Society of Biological Sciences. 363, 1811-1817.

Liu, F.W., 1978. Effects of harvest date and ethylene concentration in controlled atmosphere storage on the quality of McIntosh apples. Journal of the American Society for Horticultural Science. 103, 388-392.

Malhotra, S.K. 2017. Horticulture rops and climate change: A review. Indian Journal of Agricultural Sciences. 87(1): 12-22.

Mauzerall, D.L. and Wang, X., 2001. Protecting agricultural crops from the effects of tropospheric ozone exposure: Reconciling science and standard setting in the United States, Europe, and Asia. Annual Review of Energy and the Environment. 26, 237268.

McKeon, A.W., Warland, J. and McDonald, M.R., 2006. Long-term climate and weather patterns in reaction to crop yield: A mini review. Canadian Journal of Botany. 84, 1031-1036.

Mirza, M.M.Q, Warrick, R.A., Ericksen, N.J. and Kenny, G.J. 1998. Trends and persistence in precipitation in the Ganges, Brahmaputra and Meghna river basins. Hydrological sciences - Journal-desHydrologiques. 43(6):845-858.

Moretti, C.L., Mattos, L.M., Calbo, A.G. and Sargent, S.A., 2010. Climate changes and potential impacts on postharvest quality of fruit and vegetable crops: A review. Food Research International. 43, 18241832.

Pearson, R.C. and Goheen, A.C. 1988. Compendium of Grape Diseases. APS Press, St. Paul, MN. p. 93.

Percy, K.E., Legge, A.H. and Krupa, S.V. 2003. Troposphere ozone: A continuing threat to global forests? In: Air pollution (Ed.) D. F. E. A. Karnosky. Elsevier Ltd.: Global Change and Forests in the New Millenium. Pp. 85-118.

Perez, A.G., Sanz, C., Rios, J.J., Olias, R. and Olias, J.M., 1999. Effects of ozone treatment on postharvest strawberry quality. Journal of Agricultural and Food Chemistry. 47(4): 1652-1656.

Porritt, S.W. and Lidster, P.D., 1978. The effect of pre storage heating on ripening and senescence of apples during cold storage. Journal of the American Society for 
Horticultural Science. 103(5): 584-587.

Pouget, R., 1981. Action de la temperature sur la differenciaction des inflorescences etdusfleursdurant les phases de pre debourrement et de post debourrement des bourgeons latents de la Vigne. Conn. Vignevin. 15, 65-79.

Rajan, S. 2008. Implications of climate change in mango. Impact Assessment of Climate Change for Research Priority Planning in Horticultural Crops. Central Potato Research Institute, Shimla, Pp. 36-42.

Sage, R.F. and Kubien, D., 2007. The temperature response of $\mathrm{C} 3$ and $\mathrm{C} 4$ photosynthesis. Plant, Cell and Environment. 30, 1086-1106.

Sathisha, J. and Prakash, G.S., 2005. Influence of water and gas exchange parameters on grafted grapevines under conditions of moisture stress. South African Journal of Enology and Viticulture. 27(1): 60-65.

Singh, H.P., 2012. Ongoing research in abiotic stress due to climate change in horticulture. Indian Horticulture. 58, 3945.

Talbot, M.T. and Chau, K.V. 2002. Pre cooling strawberries agricultural and biological engineering department, Florida cooperative extension service. Gainesville: Institute of Food and Agricultural Sciences, University of Florida. Bulletin 942.
Wang, S.Y. and Zheng, W., 2001. Effect of plant growth temperature on antioxidant capacity in strawberry. Journal of Agricultural Food Chemistry. 49, 49774982.

Went, F.W., 1953. The Effect of Temperature on Plant Growth. Annual Review of Plant Physiology. 4, 347-362.

Woolf, A.B., Bowen, J.H. and Ferguson, I.B., 1999. Pre harvest exposure to the sun influences postharvest responses of 'Hass' avocado fruit. Postharvest Biology and Technology. 15, 143-153.

Woolf, A.B., Wexler, A., Prusky, D., Kobiler, E. and Lurie, S., 2000. Direct sunlight influences postharvest temperature responses and ripening of five avocado cultivars. Journal of the American Society for Horticultural Science. 125, 370-376.

Wurr, D.C.E., Fellows, J.R. and Phelps, K., 1996. Investigating trends in vegetable crop response to increasing temperature associated with climate change. Scientia Horticulturae. 66, 255-263.

Zemni, H., Souid, I., Salem, A.B.; Fathalli, N., Mliki. A., Ghorbel, A., Hammami, M. and Hellali, R., 2005. Aromatic potential of grapevines cultivated in Northern and Southern Tunisia. Acta Horticulturae. $689,87-94$.

\section{How to cite this article:}

Utpal Barua, R. P. Das and Bornali Gogoi. 2021. Response of Fruit Crops to Climate Aberration, Its Possible Affect in North East India and Mitigation Strategies - A Review. Int.J.Curr.Microbiol.App.Sci. 10(02): 06-19. doi: https://doi.org/10.20546/ijcmas.2021.1002.002 